\title{
Meanings of democracy: mapping lay perceptions on scholarly norms
}

\author{
Christian Welzel
}

Published online: 12 March 2021

(C) The Author(s) 2021

\begin{abstract}
I am grateful for the honor to write this comment because it gave me the opportunity to read this truly exquisite compilation of works collected under the editorship of Osterberg-Kaufmann, Stark and Mohamad-Klotzbach. The focus of the special section is on new frontiers in the empirical investigation of citizens' subjective understandings of democracy. It is a methodologically and phenomenologically diverse, and yet thematically cohesive, assemblage of studies that comes at due time and in which the various pieces indeed speak to each other. The compendium covers a significant portion of the innovations going on in the field of measuring lay perceptions of democracy across cultures.

To me, the key point is how lay perceptions of democracy map on scholarly norms and where and why mismatches between lay perceptions and scholarly norms exist and what the implications of such mismatches are in terms of global regime-culture coevolution. My comments to the individual articles in the special issue are framed within this broader question. I am phrasing my reflections in a more brainstorming manner, rather than systematically going through each contribution in a pointby-point style. For this reason, my discussion will not address each contribution equally but rather in terms of what I feel should loom large on our research agenda.
\end{abstract}

Comment on "Challenges in Conceptualizing and Measuring Meanings and Understandings of Democracy" by Norma Osterberg-Kaufmann, Toralf Stark and Christoph Mohamad-Klotzbach (eds.).

(Kommentar zur Special Section "Challenges in Conceptualizing and Measuring Meanings and Understandings of Democracy", hrsg. von Norma Osterberg-Kaufmann, Toralf Stark und Christoph Mohamad-Klotzbach.)

Prof. Dr. C. Welzel $(\bowtie)$

Political Culture Research Chair, Center for the Study of Democracy, Leuphana University, Lüneburg, Germany

E-Mail: cwelzel@gmail.com

Laboratory for Comparative Social Research, National Research University - Higher School of Economics, Moscow, Russia 
In a nutshell, I am advocating a decidedly cultural theory of autocracy-vs-democracy-cultural in the sense that we need to triangulate people's support for and their notions of democracy in the context of encultured values.

Keywords Autocracy · Authoritarian-vs-emancipative values · Culture $\cdot$ Culture zones · Democracy · Illiberal-vs-liberal notions of democracy $\cdot$ Regimes $\cdot$ Support for democracy

\section{Bedeutungen von Demokratie: Wie sich Laienwahrnehmungen zu wissenschaftlichen Experten-Ratings verhalten}

Zusammenfassung Ich bin dankbar für die Gelegenheit, diesen Kommentar schreiben zu dürfen - gab dies mir doch die Möglichkeit, diese wirklich exquisite Zusammenstellung von Arbeiten zu lesen, die unter der Herausgeberschaft von OsterbergKaufmann, Stark und Mohamad-Klotzbach entstand. Der Schwerpunkt des Sonderheftes liegt auf neuen Herausforderungen in der empirischen Untersuchung des subjektiven Demokratieverständnisses der Bürger und ihrer Bedeutungen. Es handelt sich um eine methodisch und phänomenologisch vielfältige und dennoch thematisch kohärente Zusammenstellung von Studien, die zur rechten Zeit kommt und in der die verschiedenen Teile tatsächlich miteinander sprechen. Das Kompendium deckt einen bedeutenden Teil der Innovationen ab, die auf dem Gebiet der Messung von Laienwahrnehmungen von Demokratie in verschiedenen Kulturen stattfinden.

Für mich ist der Schlüsselpunkt, wie Laienwahrnehmungen von Demokratie sich zu wissenschaftlich basierten Experten-Ratings verhalten und wo und warum es Diskrepanzen zwischen Laienwahrnehmungen und Experten-Ratings gibt und was die Implikationen solcher Diskrepanzen im Hinblick auf die globale Regime-KulturKoevolution sind. Meine Kommentare zu den einzelnen Beiträgen des Sonderheftes sind in diese breitere Fragestellung eingebettet. Ich formuliere meine Überlegungen eher in einer Art Brainstorming, als dass ich jeden Beitrag systematisch Punkt für Punkt bespreche. Aus diesem Grund werde ich in meiner Diskussion nicht jeden Beitrag gleichgewichtig adressieren, sondern nur insoweit ich einen zentralen Beitrag zur Forschungsagenda erkenne. Kurz gesagt, ich plädiere für eine dezidiert kulturelle Theorie von Autokratie vs. Demokratie - kulturell in dem Sinne, dass wir die Unterstützung der Menschen für und ihre Vorstellungen von Demokratie im Kontext kulturell verwurzelter Werte betrachten müssen.

Schlüsselwörter Autokratie · Autoritäre-vs-emanzipative Werte · Demokratie · Illiberale-vs-liberale Vorstellungen von Demokratie · Kultur · Kulturzonen · Regime · Unterstützung der Demokratie

\section{A brief summary}

In their introductory chapter, Osterberg-Kaufmann, Stark and Mohamad-Klotzbach (2020) present a useful dictionary of contested terms in researching lay notions of democracy and they locate the five contributions of this collection in the context 
of ongoing debates and challenges in the field. One of these debates, that between relativism and universalism, is most central in my eyes and I will come back to this issue further below. Two of the contributions (Baniamin 2020; Wegscheider and Stark 2020) are of an explanatory kind and use established survey methodology to study ordinary citizens' notions of democracy, the differences therein and the broader implications of these. The other three contributions are of a more reconstructive type in trying to paint a nuanced picture of how ordinary people understand and think about democracy. Two of these works (Dahlberg et al. 2020; Osterberg-Kaufmann and Stadelmaier 2020) pursue a mixed-methods approach in that they analyze qualitative semantic data in novel ways with quantitative methods ("repertory grid", "distributional semantics"). The third of these reconstructive studies (Frankenberger and Buhr 2020) is purely qualitative in character based on two sets of narrative interviews in Baden Wuerttemberg.

To begin with, Baniamin's analysis starts from the puzzling observation that respondents in the Afrobarometer surveys often express satisfaction with democracy and consider their own country as quite democratic, when in fact it is not (due to scholarly standards applied in expert democracy ratings by Polity, Freedom House or V-Dem). Baniamin shows convincingly that this paradox resolves itself when one divides respondents into "rights seekers" and "privilege seekers": apparently, rights seekers apply more demanding standards of judgement and, hence, are less likely to be satisfied with their country's state of democracy and also less likely to mistake their country for a democracy when it isn't one. This insight is important, intuitively plausible and novel, although I wonder in how far "rights seekers" is just rephrasing older conceptions such as "critical citizens" (Norris 1999, 2011) "intrinsic democracy supporters" (Inglehart and Welzel 2005), "grounded democracy supporters" (Welzel 2013) or "assertive citizens" (Dalton and Welzel 2014)—to name just a few "democrats with adjectives" (Schedler and Sarsfield 2007).

Using World Values Surveys data, Wegscheider and Stark (2020) demonstrate that respondents with a more sophisticated knowledge about what democracy means tend to be more satisfied with democracy and rate their country's state of democracy higher-yet this effect is conditional on a country's actual level of democracy: democratic knowledge only improves people's satisfaction with democracy in actual democracies. By implication, this means that democratic knowledge decreases people's regime support in autocracies. Although this might seem trivial, it is not because this finding implies that knowledge about democracy embodies a tendency to like democracy, which would be a true Enlightenment effect, or as Cho (2014) put it: "to know democracy is to love it." In intertwining this finding with that of Baniamin, one obvious question remains, however: how do "rights seeking" (Baniamin) and "democratic knowledge" (Wegscheider and Stark) map on each other and what's the common ground, if it exists?

At any rate, I think that the findings of Baniamin and Wegscheider/Stark are rather substantial. And they both showcase the strengths of standardized surveys. This is significant to note because a common point of departure of the next three contributions is a rather fundamental criticism of survey research, which all three of them take as a justification to present alternative methods in analyzing lay perceptions of democracy. It is also interesting to note that all three of these reconstructive pieces 
go at much greater length to explain their method than at laying out substantive findings. This could give one a pause to think.

Dahlberg, Axelsson and Holmberg's (2020) study is impressive already by the methodology just in and by itself. These authors analyze textual online data from news media and social media from all around the world in an attempt to map the semantic contexts in which the word "democracy" is used in different countries and languages. Many of the results are interesting from a descriptive point of view. For one, communitarian terms like "society," "republic" or "justice" seem most commonly linked to the word democracy, while a semantic linkage to individualistic terms such as "rights," "liberties" and "freedoms" seems to be a peculiarity of the "English West" and Northwestern Europe. In light of this insight, I would conclude that the idea of democracy as "liberal democracy" continues to be most firmly encultured in countries where the Protestant Reformation left an individualistic cultural legacy. Democracy as liberal democracy is, hence, by no means a cross-cultural universal, at least not in lay understandings. That would match the findings of Baniamin and Wegscheider/Stark.

Osterberg-Kaufmann and Stadelmaier (2020), for their part, present the innovative method of "repertory-grid" interviews among members of the Singaporean middle class. The authors demonstrate convincingly how one can distillate democratic meanings from the mindsets of non-Westerners. Singapore is chosen as an unusual case where people show a high level of satisfaction with democracy, despite the fact that the country is at best a half-democracy (echoing Baniamin's point of departure with several African examples). An explanation of this mismatch between lay perceptions and scholarly assessments of democracy in the case of Singapore might indeed reside in the subjective meanings that Singaporean citizens attribute to the term democracy: while the association of democracy with "free elections" seems to be generalizable (and Singapore does have elections, albeit not an even playing field), "equal rights" and "civil liberties" loom less importantly as terms associated with democracy. This insight as well suggests that the understanding of democracy as "liberal" democracy might be a singularity of the Protestant West. In my eyes, this insight supports the idea of "regime-culture congruence": lay persons tend to understand democracy as whatever their regime offers them as such?

Finally, Frankenberger and Buhr's (2020) point of departure is a stark criticism of standardized surveys and their alleged incapacity to uncover meanings of democracy as they really exist in people's minds. From this criticism, the authors conclude that it needs qualitative interviews to reconstruct lay perceptions of democracy in psychological authenticity. Based on two sets of qualitative interviews in BadenWuerttemberg, Frankenberger and Buhr then succeed in demonstrating that lay people's conceptions of democracy are indeed more complex than standard surveys are able to show. This study brings home this point persuasively, but not much more: it does not become obvious where the added explanatory value is in showing that the world is somewhat more complex than scientific models assume. In my eyes, the question to be addressed to quantitative survey research is not whether it reconstructs reality in perfect authenticity but whether it models reality in sufficient adequacy to generate explanatory/predictive value. As far as I see it, the contribu- 
tions of Baniamin and Wegscheider/Stark are convincing in answering this question affirmatively.

\section{Thoughts beyond}

What thoughts does this compilation of five works provoke? Let me start with the assertion that each of the five studies, in one way or the other, contributes to demolish what Kirsch and Welzel (2018) have called the "a-cultural view of democracy" and which — unfortunately — continues to be advocated by scholars like Waldner and Lust (2019). The key point of departure of the a-cultural view is ample evidence showing that public support for democracy is seemingly widespread all around the world, and even more so in autocracies than in democracies (Maseland and van Hoorn 2012). This repeatedly confirmed finding has been taken to mean that the desire for democratic freedoms is not contingent on encultured values but is universally human-so to speak an anthropological constant.

The a-cultural view of the human desire for democracy involves some strong assumptions. For one, scholars assume that when people express that they support democracy, they have pretty much the same thing in mind-namely Western liberal democracy (Dalton et al. 2007). Thus, people who express a desire for democracy in an autocracy realize perfectly well that they actually live in an autocracy and, therefore, express with this desire their wish for a regime change. Autocracies, in this view, are almost never legitimate in the eyes of their citizens and always exist in oppression of the majority's dissenting preference for democracy.

This a-cultural view resonates with the median voter theorem in political economy (Acemoglu and Robinson 2006). The median voter represents the majority and naturally desires democracy because elections empower the majority to translate its interests into public policy. Consequently, regime variation in autocracy-vs-democracy has little to do with differences in public regime preferences, simply because the people always anyways want democracy. Thus, where people have the bad luck to be ruled by autocrats, one only has to remove the tyrants to pave the way for people's natural desire for democracy. Such views informed Western foreign policy, nurturing the belief that removing the Taliban, Saddam and Gaddafi from power would turn Afghanistan, Iraq and Libya automatically into democracies.

Seemingly confirming the a-cultural view of democracy, we know that variation in public support for democracy explains very little, if any, regime variation in autocracy-vs-democracy (Hadenius and Teorell 2005; Fails and Pierce 2008). However, variation in authoritarian-vs-emancipative values ${ }^{1}$ and variation in illiberal-vs-liberal understandings of democracy explains substantial regime variation in autocracy-vs-

\footnotetext{
1 Using data from the World Values Surveys (www.wordlvaluessurvey.org; Haerpfer et al. 2020) for about a hundred countries, emancipative values measure support for universal freedoms by combining responses to four themes, each of which comprises three questions, including (1) gender equality (support for women's equal access to education, jobs and politics), (2) child autonomy (independence, imagination and nonobedience as desired child qualities), (3) public voice (support for freedom of speech and public participation in local, job and national affairs) and (4) reproductive freedoms (tolerance of homosexuality, abortion
} 
democracy (Kirsch and Welzel 2018; Kruse et al. 2018; Brunkert et al. 2019; Welzel 2021). Indeed, where authoritarian values prevail, many people understand democracy in illiberal terms and mistake autocratic regime features for democratic ones. Where this is the case, support for democracy expressed in interviews turns into its own negation - support for autocracy, that is.

The propaganda of autocrats deliberately nourishes misperceptions of democracy as obedience to rulers. As a matter of fact, most autocracies call themselves democracies (Brown 2001; Marquez 2016). Chinese leaders depict their country since recently as the world's "greatest democracy." The usual indoctrination denigrates Western democracies as overly liberal perversions of "true" democracy, which is presented as a form of "guardianship" by which "wise" rulers govern in the best of people's interest. In return for such "enlightened" rulership, the people owe their leaders obedience. Schools, the media and other institutions under government control all disseminate those guardianship tales, which vary from culture to culture in attire but not in substance. Across the globe, the World Values Surveys exhibit an astoundingly large percentage of people (easily above 50\% in many places) who indeed misunderstand democracy as "people obey their rulers" (note that even though democratic citizens are expected "to abide by the laws," they are not expected "to obey their rulers"). However, people who endorse emancipative values resist these and other misunderstandings - and this resistance is not mediated by regime type: it is as robust in autocracies as in democracies (Welzel 2021: Fig. 9). There are just fewer people who embrace emancipative values in autocracies than in democracies, which actually explains part of the global regime variation in autocracy-vsdemocracy.

Consequently, lip service to democracy is an altogether inconclusive indicator of political culture. Public support for democracy has predictive power over regime variation in autocracy-vs-democracy only on the condition that this support associates with emancipative values and liberal understandings of democracy. Fig. 1 illustrates this in impressive clarity: the two left-hand diagrams measure public support for democracy on the condition that this support associates with emancipative values (Diagram 1.1) or that this support associates with liberal understandings of democracy (Diagram 1.3). Since emancipative values in turn closely correlate with liberal notions of democracy, both diagrams basically convey the same message: conditional on either emancipative values or liberal understandings, support for democracy explains some $65 \%$ of the global regime variation in autocracy-vsdemocracy. The two right-hand diagrams, by contrast, show that when we untie support for democracy from either emancipative values (Diagram 1.2) or liberal un-

and divorce). Index scores vary between 0 at the authoritarian end and 1.0 at the emancipatory end, with multiple decimal fractions for intermediate positions. Sect. 1 of the Online Appendix documents the index construction. Besides, there is a dispute about the measurement equivalence of emancipative values. Alemán and Woods (2015) and Sokolov (2018) claim that emancipative values do not measure the same concept across countries because the constituent items show different factor loadings in different countries. Brunkert et al. (2021), by contrast, demonstrate that "compositional substitutability" allows different items to substitute each other's function in different countries, for which reason non-invariance in factor loadings is no measurement problem. 

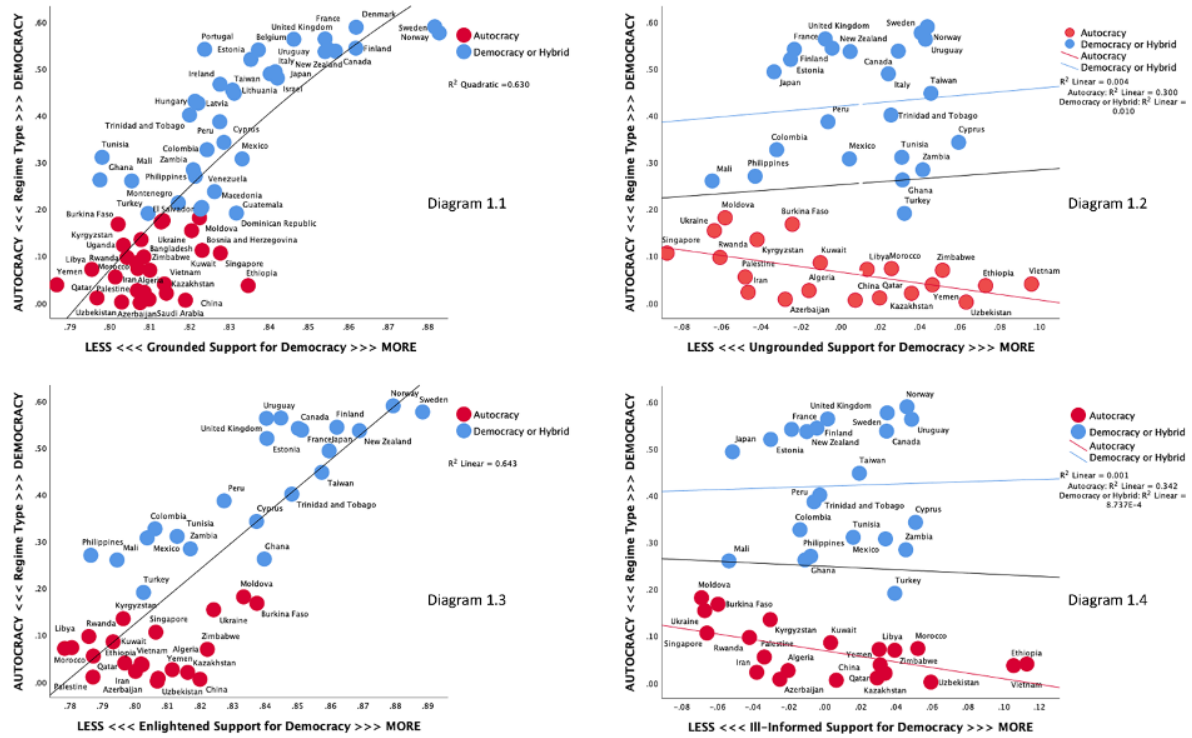

Fig. 1 Conditional and Unconditional Regime Effects of Public Support for Democracy. Note: Vertical axes display Brunkert et al.'s (2019) measure of "comprehensive democracy," which is a multiplicative combination of V-Dem's (www.v-dem.org) electoral, liberal and participative democracy components (Lindberg et al. 2020). "Grounded Support for Democracy" on the horizontal axis in Diagram 1.1 are predicted scores in support for democracy by authoritarian-vs-emancipative values. "Ungrounded Support for Democracy" on the horizontal axis in Diagram 1.2 are residual scores in support for democracy unpredicted by authoritarian-vs-emancipative values. "Enlightened Support for Democracy" on the horizontal axis in Diagram 1.3 are predicted scores in support for democracy by illiberal-vs-liberal notions of democracy. "Ill-Informed Support for Democracy" on the horizontal axis in Diagram 1.4 are residual scores in support for democracy unpredicted by illiberal-vs-liberal notions of democracy. The regressions underlying all these predicted and residual scores are conducted with country-level aggregations of support for democracy, illiberal-vs-liberal notions of democracy and authoritarian-vs-emancipative values, as explained in Welzel (2013: Chap. 2 and 9). The data are from the World Values Surveys (WVS) (www.worldvaluessurvey.org), using the latest available survey for each country (Haerpfer et al. 2020). Hence, temporality of measurements varies between 1996 and 2018, with 2011 being the mean and median year of observation. Democracy measures from V-Dem are taken from the same year as survey data from the WVS

derstandings (Diagram 1.4), support for democracy completely loses its explanatory power over regime variation in autocracy-vs-democracy.

Of course, whether this means that mentalities shape compatible regimes or whether regimes enculture fitting mentalities does not reveal itself from this associational evidence. But either way, it is clear that culture-regime congruence does exist, although it remains invisible with unconditional measures of support for democracy. Besides, Claassen's (2019) finding that more widespread support for democracy makes democracies resilient to backsliding into authoritarianism does not contradict this conclusion: Claassen, too, measures support for democracy conditionally (including into the measure the rejection of authoritarian alternatives to democracy). 


\section{Normative universalism vs. cultural relativism}

Does the cross-cultural variety in lay perceptions of democracy justify a softening and "de-Westernization" of democracy's normative definition? In their introductory chapter, Osterberg-Kaufmann, Stark and Mohamad-Klotzbach discuss this question under the title universalism vs. relativism and leave much room to authors like Dallmayr (1997) and Yildiz (2012) who argue that way. These and other authors diagnose a "Eurocentric hegemony" in scholarly definitions of democracy that must be overcome, so as to decolonize the concept. Arguments such as these invoke cultural pluralism to conclude that each culture is entitled to develop its own variety of democracy.

Here, I disagree. Redefining democracy as whatever lay persons understand as such is to throw over board the concept's very normativity. It is a simple matter of logic that in order to keep democracy a concept useful for meaningful comparison, the normativity in its definition must be retained-period.

This does not mean that we should not measure lay perceptions of democracy as they are-quite the contrary, we should do exactly that. Yet, we should still treat lay perceptions as just perceptions and hold them against a scholarly yardstick under the-yes-normative question of how much the documented lay perceptions deviate from scholarly norms, such as those defined by Polity, Freedom House or V-Dem. Only then can we study how successful authoritarian propaganda is in implanting into people's minds a manipulated understanding of democracy and what forces operate effectively against such indoctrination. If we want political science to be an instrument in defense of democracy, we of course need empirical research that mirrors lay perceptions of democracy as they are, but we nevertheless need to uphold democracy as a scholarly defined norm in order to be able to call a misperception as what it is. Democracy is a concept of Western origin and softening its normative core for the sake of cultural pluralism would make the concept meaningless and delegitimize such fruitful endeavors as V-Dem (Lindberg et al. 2020). This is not to deny that the normative core of democracy is variegated. In fact, its variability is V-Dem's whole point of departure, offering researchers a choice between concepts with a more narrow normative core ("electoral democracy") and concepts with a broader normative core ("participatory democracy"). But one thing is true despite this versatility: there is scholarly consent that the norms of electoral democracy (i.e., contestation for legislative and executive power in regular, free and fair elections under universal suffrage) constitute the minimum standard against we measure each country's democratic reality. We should also measure lay perceptions of democracy against this standard.

It is a logical fallacy of monumental gravity to conclude that the normative core of the concept of democracy needs to be de-standardized because large amounts of lay people misconceive this normative core. If we want to map lay perceptions on normative meanings, the possibility of mismatches must be logically included. This possibility, however, is eliminated when we mandate that the normative core should accord to the lay perception. The game we should play is not to adjust scholarly norms to lay perceptions but to map lay perceptions on scholarly norms in order to identify misperceptions. Only under a normative judgement of empirical realities 


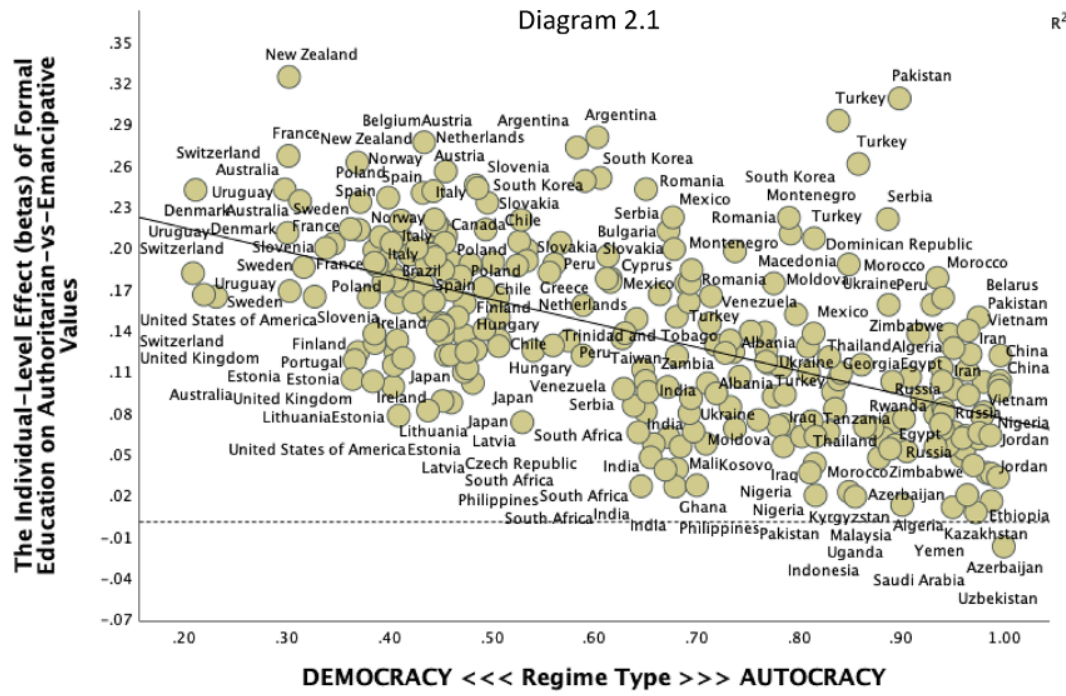

$R^{2}$ Linear $=0.327$

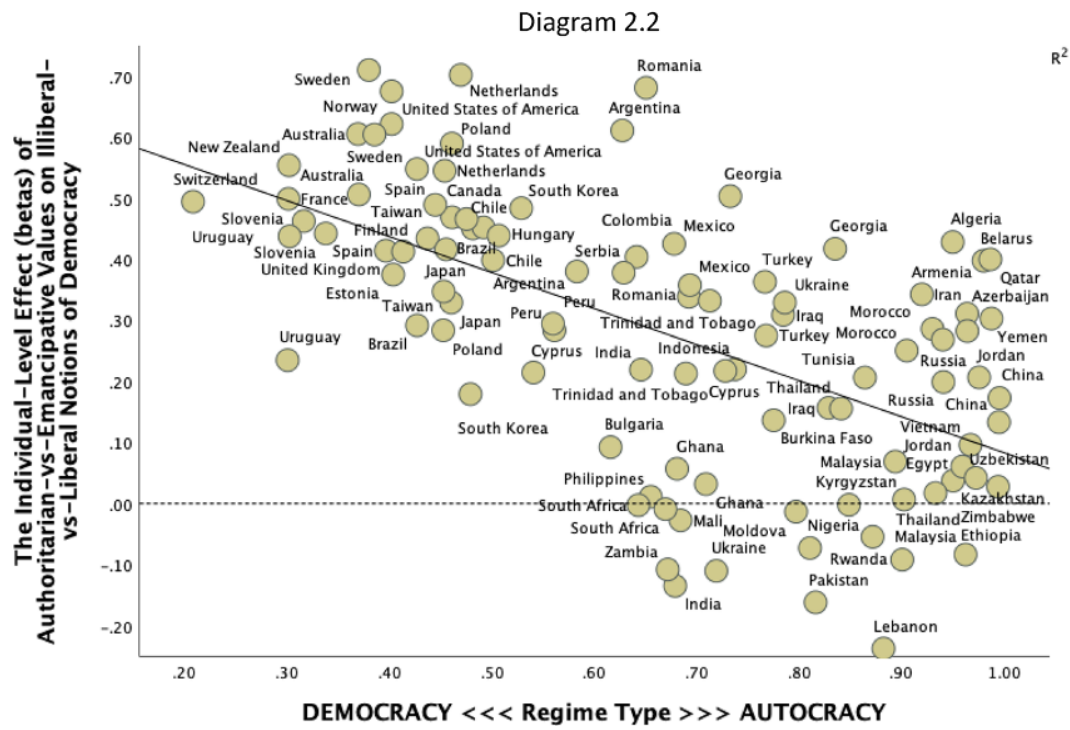

Fig. 2 The Moderation of Two Enlightenment Effects by Regime Type. Notes. The horizontal axes in both diagrams display the inver se of the democracy measure on the vertical axes in Fig. 1 based on V-Dem data, showing how autocratic countries are. The vertical axis in Diagram 2.1 displays standardized regression coefficients (betas) obtained from regressing individual-level authoritarian-vs-emancipative values on formal education, separately for each country. The vertical axis in Diagram 2.2 follows a similar logic and displays standardized regression coefficients (betas) obtained from regressing individual-level illiberal-vsliberal notions of democracy on authoritarian-vs-emancipative values. Data are from the World Values Surveys and cover all countries and waves with available data. For data sources, see footer in Fig. 1 
are we able to study the sources and consequences of these realities in a meaningful manner.

\section{Remaining questions}

Against this backdrop, the most interesting questions that still deserve more research (including surveys) can be phrased as follows: How similar and dissimilar are lay perceptions of democracy across cultures on the illiberal-vs-liberal notions continuum? To what extent do these lay perceptions deviate from scholarly definitions of liberal democracy and where and why are such deviations particularly prevalent? What role does autocratic propaganda play in feeding such deviations? Does formal education (which expands everywhere in the world) generally give rise to emancipative values and do these values generally diminish illiberal misperceptions of democracy — or are these two enlightenment effects contingent on regime type?

The latter question is particularly critical because in the global regime competition between autocracies and democracies, autocracies must succeed in suffocating precisely these two enlightenment effects. Otherwise, expanding education and other cognitively mobilizing aspects of modernization are undermining autocratic legitimacy.

The evidence in Fig. 2 provides some preliminary answers to these questions, which are essential in the context of global regime evolution. As it seems, the degree to which democracy is absent and autocracy present does indeed diminish the two enlightenment effects, and quite significantly so. However, autocracy does by no means entirely turn off the two enlightenment effects, let alone turn them around. The absence of such a turn-around effect will surprise scholars like Sniderman (1975) who advocate the idea that formal education always infuses into people the norms of the regime in place, no matter if the regime is autocratic or democratic. If so, education should make people the more authoritarian in their values and the more illiberal in their notions of democracy, the more autocratic the regime is under which this education is organized. Obviously, such a mind-twisting role of regime type does not exist: the two effects in question are almost everywhere in the positive zone, autocracies included. This finding justifies a less gloomy assessment of autocracies' ability to brainwash their citizens. This is something we can learn from survey research, although much more detailed research on these issues is needed.

\section{Concluding remark}

At any rate, the community should not lose out of sight in its research agenda the original inspiration of modern democracy in Enlightenment thought. Throwing over board this normative anchor for the sake of cultural pluralism (or postcolonial theory and other esoteric post-positivism ideas) will make the concept of democracy meaningless. Taking that route will only proliferate more "democracies with adjectives" (Collier and Levitsky 1997), like most recently China's self-portrayal as the world's "greatest democracy." The academic use of the term democracy needs to be saved 
from autocratic propaganda. Advocating cultural relativism is the wrong recipe to achieve this goal.

Funding Open Access funding enabled and organized by Projekt DEAL.

Open Access This article is licensed under a Creative Commons Attribution 4.0 International License, which permits use, sharing, adaptation, distribution and reproduction in any medium or format, as long as you give appropriate credit to the original author(s) and the source, provide a link to the Creative Commons licence, and indicate if changes were made. The images or other third party material in this article are included in the article's Creative Commons licence, unless indicated otherwise in a credit line to the material. If material is not included in the article's Creative Commons licence and your intended use is not permitted by statutory regulation or exceeds the permitted use, you will need to obtain permission directly from the copyright holder. To view a copy of this licence, visit http://creativecommons.org/licenses/by/4. $0 /$.

\section{References}

Acemoglu, Daron, and James A. Robinson. 2006. Economic origins of democracy and dictatorship. New York: Cambridge University Press.

Alemán, José, and Dwayne Woods. 2015. Value orientations from the world values survey. Comparative Political Studies 49:1039-1067.

Baniamin, Hasan Muhammad. 2020. Citizens' inflated perceptions of the extent of democracy in different African countries. Zeitschrift für Vergleichende Politikwissenschaft 14:321-343.

Brown, Archie. 2001. From democratization to "guided democracy". Journal of Democracy 12:35-41.

Brunkert, Lennart, Stefan Kruse, and Christian Welzel. 2019. A tale of culture-bound regime evolution: the centennial democratic trend and its recent reversal. Democratization 26:422-443.

Brunkert, Diane L., Ronald Inglehart, Stefan Kruse, and Christian Welzel. 2021. Non-Invariance? On overstated problem with misconceived causes. Sociological Methods and Research 50. Forthcoming.

Cho, Youngho. 2014. To know democracy is to love it. Political Research Quarterly 67:478-488.

Claassen, Christopher. 2019. Does public support help democracy to survive? American Journal of Political Science 64:118-134.

Collier, David, and Steven Levitsky. 1997. Democracy with adjectives. World Politics 49:430-451.

Dahlberg, Stefan, Sofia Axelsson, and Sören Holmberg. 2020. Democracy in context: using a distributional semantic model to study differences in the usage of democracy across languages and countries. Zeitschrift für Vergleichende Politikwissenschaft 14:425-459.

Dallmayr, Fred. 1997. Introduction: toward a comparative political theory. The Review of Politics 9(13):421-428.

Dalton, Russell J., and Christian Welzel (eds.). 2014. The civic culture transformed: from allegiant to assertive citizens. New York: Cambridge University Press.

Dalton, Russell J., Shin Doh Chull, and Willy Jou. 2007. Understanding democracy. Journal of Democracy 18:142-156.

Fails, Matthew D., and Heather Nicole Pierce. 2008. Changing mass attitudes and democratic deepening. Political Research Quarterly 63:174-187.

Frankenberger, Rolf, and Daniel Buhr. 2020. "For me Democracy is ..." meanings of democracy from a phenomenological perspective. Zeitschrift für Vergleichende Politikwissenschaft 14:375-399.

Hadenius, Axel, and Jan Teorell. 2005. Cultural and economic prerequisites of democracy. Studies in Comparative International Development 39:87-106.

Haerpfer, Christian, Ronald Inglehart, Alejandor Moreno, Christian Welzel et al. (eds.). 2020. World values surveys: time series 1981-2020. Madrid: JD Systems Archive. release version 11/2020.

Inglehart, Ronald, and Chrisitan Welzel. 2005. Modernization, cultural change and democracy. New York: Cambridge University Press.

Kirsch, Helen, and Christian Welzel. 2018. Democracy misunderstood: authoritarian notions of democracy around the globe. Social Forces 91:1-33.

Kruse, Stefan, Maria Ravlik, and Christian Welzel. 2018. Democracy confused: when people mistake autocracy for democracy. Journal of Cross-Cultural Psychology 49:1-21.

Lindberg, S., M. Coppedge, J. Gerring, et al. 2020. The V-Dem Dataset (release version ___). Gothenburg: V-Dem Institute.

Marquez, G. 2016. Non-democratic politics. London: Palgrave. 
Maseland, Robbert, and André van Hoorn. 2012. Why Muslims like democracy yet have so little of it. Public Choice 147:481-497.

Norris, Pippa (ed.). 1999. Critical citizens. New York: Cambridge University Press.

Norris, Pippa. 2011. Democratic deficit. New York: Cambridge University Press.

Osterberg-Kaufmann, Norma, and Ulrich Stadelmaier. 2020. Measuring Meanings of Democracy—methods of differentiation. Zeitschrift für Vergleichende Politikwissenschaft 14:401-423.

Osterberg-Kaufmann, Norma, Toralf Stark, and Christoph Mohamad-Klotzbach. 2020. Challenges in conceptualizing and measuring meanings and understandings of democracy. Zeitschrift für Vergleichende Politikwissenschaft 14:299-320.

Schedler, Andreas, and Rodolf Sarsfield. 2007. Democrats with adjectives. European Journal of Political Research 46:637-659.

Sniderman, Paul M. 1975. Personality and democratic politics. Berkeley: University of California Press.

Sokolov, Boris. 2018. The index of emancipative values. American Political Science Review 113:1-14.

Waldner, David, and Ellen Lust. 2019. Unwelcome change: coming to terms with democratic backsliding. Annual Review of Political Science 18:93-113.

Wegscheider, Carsten, and Toralf Stark. 2020. What drives citizens' evaluation of democratic performance? The interaction of citizens' democratic knowledge and institutional level of democracy. Zeitschrift für Vergleichende Politikwissenschaft 14:345-374.

Welzel, Christian. 2013. Freedom rising; human empowerment and the quest for emancipation. New York: Cambridge University Press.

Welzel, Christian. 2021. Democratic horizons: what value change reveals about the future of democracy. Democratization 28:. forthcoming.

Yildiz, Taylan. 2012. Übersetzungspraktiken und die widersprüchliche Logik des Politischen. In Nichtwestliches politisches Denken, ed. Holger Zapf, 213-228. Wiesbaden: Springer. 